\title{
A Summary of the California Public Utilities Commission's Two Competing Electric Utility Restructuring Proposals
}

Kevin Porter

National Renewable Energy Laboratory 1617 Cole Boulevard Golden, Colorado 80401-3393

A national laboratory of the U.S. Department of Energy Managed by Midwest Research Institute under Contract No. DE-AC36-83CH10093

Prepared under Task No. AS115009

November 1995 


\section{NOTICE}

This report was prepared as an account of work sponsored by an agency of the United States government. Neither the United States government nor any agency thereof, nor any of their employees, makes any warranty, express or implied, or assumes any legal liability or responsibility for the accuracy, completeness, or usefulness of any information, apparatus, product, or process disclosed, or represents that its use would not infringe privately owned rights. Reference herein to any specific commercial product, process, or service by trade name, trademark, manufacturer, or otherwise does not necessarily constitute or imply its endorsement, recommendation, or favoring by the United States government or any agency thereof. The views and opinions of authors expressed herein do not necessarily state or reflect those of the United States government or any agency thereof.

Available to DOE and DOE contractors from:

Office of Scientific and Technical Information (OSTI)

P.O. Box 62

Oak Ridge, TN 37831

Prices available by calling (615) 576-8401

Available to the public from:

National Technical Information Service (NTIS)

U.S. Department of Commerce

5285 Port Royal Road

Springfield, VA 22161

(703) $487-4650$ 


\section{Preface}

A Swnnary of the California Public Utilities Commission's Two Competing Electric Utility Restructuring Proposals was prepared by the Analytic Studies Division for the Competitive Resource Strategies (CRS) program in the Office of Utility Technologies (OUT) at the U.S. Department of Energy (DOE). The paper is designed to inform staff at NREL and DOE and interested renewable energy stakeholders of developments in the state that has made some of the most significant proposals in restructuring its electric power industry, and to discuss the implications of the two proposals for renewable energy technologies. The views in this paper are those of the author and do not necessarily represent those of NREL or DOE.

The author wishes to thank the following for reviewing drafts of this paper: Karin Sinclair, Blair Swezey, Paul Galen, and Jeff Fang of NREL; Jack Cadogan of the Wind/Hydro/Ocean Division of DOE; Val Jensen of the Competitive Resource Strategies (CRS) program in OUT; David Morse of the Division of Ratepayer Advocates of the California Public Utilities Commission; Nancy Rader, a consultant to the American Wind Energy Association; Jan Hamrin of Hansen, McOuat, Hamrin \& Rohde; and Scott Hempling, attorney at law.

Approved for the

NATIONAL RENEWABLE ENERGY LABORATORY

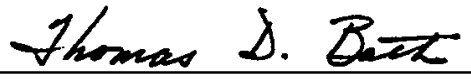

Thomas D. Bath, Director

Analytic Studies Division

\section{Eedoc Bren}

Eldon Boes, Manager

Programmatic Studies Office 


\section{Contents}

$\underline{\text { Page }}$

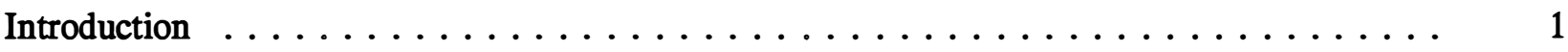

The Proposals $\ldots \ldots \ldots \ldots \ldots \ldots \ldots \ldots \ldots \ldots \ldots \ldots \ldots \ldots \ldots \ldots \ldots \ldots$

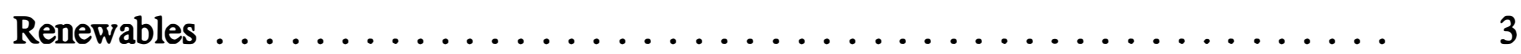

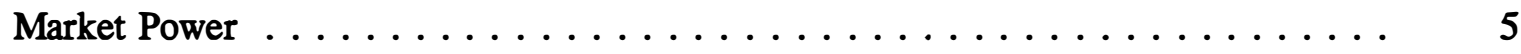

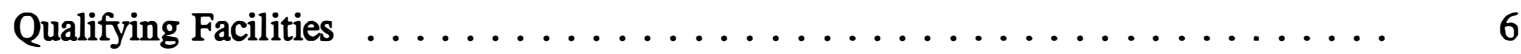

Performance-Based Ratemaking and Incentives . . . . . . . . . . . . . . . 6

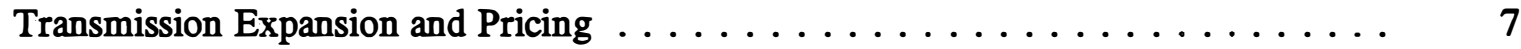

Stranded Investment $\ldots \ldots \ldots \ldots \ldots \ldots \ldots \ldots \ldots \ldots \ldots \ldots \ldots$

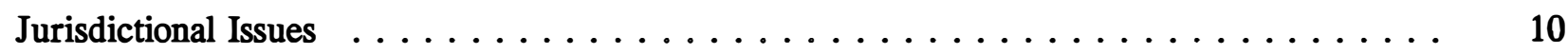

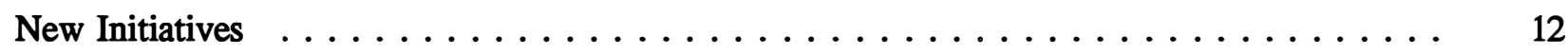

The Memorandum of Understanding $\ldots \ldots \ldots \ldots \ldots \ldots \ldots \ldots \ldots$

Customer Groups . . . . . . . . . . . . . . . . . . . . . 13

Environmental, Public Interest, and Renewable Energy Groups . . . . . . . . . . 14

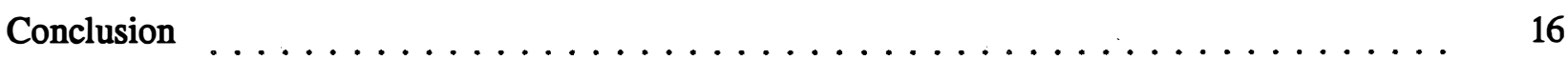

References $\ldots \ldots \ldots \ldots \ldots \ldots \ldots \ldots \ldots \ldots \ldots \ldots \ldots \ldots \ldots \ldots \ldots \ldots \ldots \ldots$

Appendix-A Comparison of Electric Utility Restructuring Proposals Before the California Public Utilities Commission . . . . . . . . . . . . . . . . . 19 


\section{Introduction}

In May 1995, the California Public Utilities Commission (CPUC) released two proposals for restructuring the state's electric power industry. The two proposals follow more than a year of testimony and public comment after the CPUC issued the "Blue Book" (CPUC 1994a) on April 20, 1994, which called for retail wheeling to be phased in to all customers over 5 years.

The majority proposal, supported by three of the four CPUC commissioners (one seat was vacant when the proposals were released), calls for creating a central pool, or "poolco"; setting electric prices to reflect true costs of service, or "real-time pricing"; and allowing parties to negotiate "contracts for differences" between the pool price and the contract price. The minority proposal, sponsored by Commissioner Jesse Knight, calls for retail wheeling, or "direct access," and for utilities to divest or spin off their generating assets.

The two proposals will further contribute to an already massive public record. More than 150 parties participated in last year's docket, which consisted of four full-panel hearings, 24 public hearings, and separate hearings on recovery of stranded costs from converting to a new regulatory and utility regime. More than 15,000 pages of testimony and public record are part of the docket, with more coming.

At the 1995 summer meetings of the National Association of Regulatory Utility Commissioners (NARUC) in San Francisco, CPUC President Daniel Fessler said the CPUC plans to release an initial policy decision in October 1995, hold "implementation" hearings devoted to fine tuning the decision, then issue a final order in January 1996. Both proposals call for implementation by January 1, 1997, which is highly ambitious, especially if the CPUC does not stick to President Fessler's schedule.

This paper presents a summary of the major provisions of the two CPUC proposals and the possible implications and issues associated with each. It is aimed at researchers who may be aware that various efforts to restructure the electric power industry are under way and want to know more about California's proposals, as well as those who want to know the implications of certain restructuring proposals for renewable energy technologies. Presented at the end of the paper is a summary of alternative proposals promoted by various stakeholders in response to the two CPUC proposals. 


\section{The Proposals}

This report primarily two proposals, both issued May 24, 1995, by the California Public Utilities Commission to fundamentally restructure the electric utility industry and the state's regulation of the utility industry. The two proposals are (1) Knight, The Honorable Jesse J., Consumer Choice Through. Direct Access: Charting a Sustainable Course to a Competitive Electric Services Industry (Knight proposal), and (2) the majority proposal (untitled). A summary of alternative proposals prepared by various stakeholders is presented near end of this report.

The Knight proposal cites two major barriers to greater competition in the electric utility market: (1) consumers cannot voluntarily select electric services from other providers and (2) electric utilities' dominance of generation assets gives them considerable market power that requires mitigation. The Knight proposal calls for five fundamental industry changes to promote competition: (1) elimination of the existing monopoly structure; (2) separation of a utility's generation service operations from the delivery side of its business; (3) protection of the utility's fair and reasonable opportunity to earn and a promise to "honor the regulatory bargains of the past," (4) nondiscriminatory transmission and distribution services; and (5) performance-based regulation (PBR) for customers of the distribution utility. The Knight proposal calls for direct access through bilateral contracts between buyers and sellers within 2 years once certain conditions have been met. It also calls for the divestiture or spin-off of utility generation assets to mitigate market power and to serve as a basis for determining stranded cost recovery. A distribution utility would be created to serve customers who do not wish to participate in direct access. An independent system operator (ISO), or operating company (OPCO), would be created to ensure reliability by providing ancillary and back-up services. Dispatch would be based on the price determined through bilateral contract negotiations, not by central bidding conducted by the ISO.

The majority proposal consists of a central pool, real-time pricing, and contracts for differences. Utilities must transfer the control and dispatch functions of their transmission systems to an ISO, although they would retain ownership of the actual transmission assets. The three investor-owned utilities in California would be required to make all their sales and purchases from the pool; Pacificorp and Sierra Pacific may be required to participate as well. The CPUC does not have the authority to require municipal utilities, out-of-state utilities, or independent power producers (IPPs) to participate, although the majority plainly hope they will decide to join. Existing QF and wholesale contracts, as well as investor-owned utility nuclear and hydro plants, would be dispatched from the pool first. Suppliers-basically the investorowned utility geothermal and coal plants and participating public utilities, rural electric cooperatives, IPPs, and out-of-state suppliers-would submit bids to the pool in specific time increments, probably on a half-hour or hourly basis. Buyers would submit demand bids in the same time increments. With this data, the independent system operator would post market clearing prices, i.e., "spot" prices. Successful bidders would receive a market-clearing price; the majority asks for comments on whether this price should be the lowest losing bid or the last generator picked by the pool. The majority proposal suggests retail access could be mimicked through direct contracts for differences with suppliers. Real-time pricing also would be implemented in place of the average, bundled utility rate that applies no matter when service is taken.

Both proposals suggest a January 1, 1997, implementation date. The Knight proposal would not become effective until the CPUC has a stranded cost recovery mechanism in place. It would unbundle utility services; establish retail, nondiscriminatory, and comparable transmission service; and implement "any other necessary changes to California's regulatory program to ensure consumers have access to competitive markets and service providers have a fair opportunity to compete." The majority proposal does not include such provisions, although it suggests a shortage of real-time meters could force a phasein of real-time pricing over 6 years. The majority proposal would permit direct access 2 years after the pool is running but only if certain conditions are met. 
Some interesting questions to be considered are (1) whether enough load remains after existing QF and wholesale contracts and nuclear and hydro plants are dispatched for the pool to function as a competitive market, and (2) whether enough out-of-state sellers, IPPs, and municipals will participate to create effective competition in the pool. The majority proposal acknowledges that only a small percentage of generating resources, "if any," will be dispatched on a competitive basis. It is also not clear whether outof-state sellers, IPPs, or municipals would participate in the pool. IPPs and municipal utilities may believe they have better opportunities through bilateral contracts with other suppliers. In addition, municipal utilities that own transmission may be wary that FERC will require them to provide transmission access to third parties as a condition of participating in the pool.

Another issue is coordinating the control areas and the associated software among the three investorowned utilities, regardless of whether the poolco in the majority proposal or the OPCO in the Knight proposal is adopted. Consolidating the three utilities' control and dispatch areas and integrating the control areas' computer systems and software will pose unprecedented challenges that were largely unaddressed in either proposal. The technical and coordination issues alone could delay the implementation of either proposal, much less the political, legal, or regulatory issues.

\section{Renewables}

The California Public Utilities Code directs the CPUC to set aside a part of needed electric capacity for renewable resources until the CPUC adopts a resource procurement methodology that "values the environmental and diversity costs and benefits associated with various generation technologies." The CPUC implemented the statute in 1992 by setting aside almost $600 \mathrm{MW}$ for renewable energy of the more than $1300 \mathrm{MW}$ the CPUC believed electric utilities needed as part of the Biennial Resource Plan Update (BRPU) (Morse 1994). After a bidding auction in 1993 and various administrative rulings and utility appeals in 1994, FERC issued a declaratory ruling in February 1995 stating that the BRPU bidding process did not meet the requirements of the Public Utility Regulatory Policies Act (PURPA) because the bidding process was limited to QFs and PURPA requires "all sources" of electric supply to be included. ${ }^{1}$ After FERC upheld its order upon rehearing, ${ }^{2}$ CPUC President Fessler issued guidelines with the main goal of encouraging settlements to minimize litigation. Fessler's guidelines emphasized that actual projects should be built and operated, and each utility's settlement should, in total, meet the state's statutory mandates (including the renewables statute), add capacity that lowers the overall system operating cost, meet reliability needs, and be in the ratepayers' interest. Each utility can file only one application with all of the settlements it wishes the CPUC to approve (Morse 1995).

Considering how electric utility restructuring could affect public policy issues such as renewable energy technologies was the focus of a working group convened by the CPUC in December 1994. The CPUC directed the working group to address how restructuring would affect various social, environmental, and economic obligations presently carried out by electric utilities and to propose various strategies for maintaining social, environmental, and economic policy goals after electric utility restructuring. The working group, consisting of power marketers, utilities, consumer groups, environmental groups, fuel producers, farm organizations, and municipalities, submitted its recommendations to the CPUC on February 22, 1995. Both proposals contemplate reconvening the working group to further address public policy issues such as demand-side management, utility research and development, and renewable energy technologies.

\footnotetext{
${ }^{1}$ Southern California Edison Co. and San Diego Gas \& Electric Co., 70 FERC ๆ 61,215 (1995).

${ }^{2}$ Southem California Edison Co. and San Diego Gas \& Electric Co., Order on Requests for Reconsideration, 71 FERC ๆ 61,269 (1995).
} 
For renewables, the working group forwarded five options: (1) require utilities to buy specified amounts of renewables, with funding provided through a usage-based, nonbypassable charge on all customers; (2) impose a minimum renewable energy requirement for suppliers or purchasers; (3) form a statewide entity or consortium, also financed by a usage-based, nonbypassable charge, to buy renewable energy and resell it in the bulk power market; (4) create financial incentives for renewables, which also could be funded by the usage-based, nonbypassable charge; and (5) provide no renewable energy requirements or incentives at all (Working Group 1995).

For the short term, both the majority and Knight proposals would require the utilities to observe California's renewables statute, with neither imposing a renewables target. Both cite the present level of renewable QFs as justification for not imposing renewable level targets on electric utilities. The Knight proposal states that of 10,000 MW of non-utility power in California, $4500 \mathrm{MW}$ are from renewable sources. Neither proposal was definitive on this issue, however. The Knight proposal stated that "minimum resource diversity targets" could be imposed on utilities if new resources are necessary, while the majority proposal said resource diversity targets could be set for utility purchases from the pool.

For the longer term, both proposals abandon the BRPU and adopt the portfolio standard proposed by the American Wind Energy Association (AWEA) to meet the renewables requirement, although details are left to either the California state legislature (the majority proposal) or to a task force (the Knight proposal). The portfolio standard would impose a minimum renewable energy requirement for those participating in state bulk power markets. The renewables obligation would be tradeable, meaning bulk power participants with renewables in excess of the portfolio standard could sell "credits" to other bulk power participants needing more renewables. The tradeable part of the portfolio standard is modeled after the $\mathrm{SO}_{2}$ emission trading standards in the 1990 amendments to the Clean Air Act (AWEA n.d.).

At least for the short term, neither proposal appears to take into account the toll "year 11" may take on renewable facilities. Many non-utility renewable energy plants in California receive energy payments that were based on projections of high fossil fuel prices, with payments fixed during the first 10 years of a 30 -year contract. For the remaining 20 years, the energy portion of the contract is based on short-run avoided costs, primarily short-term fossil fuel prices. Because natural gas prices are low, the drop in the energy portion of these QF contracts after the first 10 years is dramatic, to roughly $3 \mathrm{c} / \mathrm{kWh}$. Some estimate revenue reductions for QF contract holders could be as much as $60 \%$, which could threaten the viability of a number of QF projects (Kito 1992). More than $50 \%$ of these contracts will be in "year 11" by 1998 , increasing to $90 \%$ by the year 2000 (Hamrin 1994). The Knight proposal uses year-old data that may overestimate the present installed capacity of renewables. At least 11 biomass power plants representing $150 \mathrm{MW}$ of net capacity have shut down since 1994. Other industry sources believe that roughly half of the 60 biomass plants in California have shut down since the beginning of 1995 . Some of these biomass plants are not very efficient, and other renewable energy technologies may not have the same attrition rate, but it is unrealistic to expect that $45 \%$ of non-utility capacity in California will continue to be renewables based.

If non-utility renewable energy capacity does decrease, an interesting issue is how California's renewables statute would be implemented. The statute only requires a certain percentage of new generating capacity to be set aside for renewables; it does not appear to address what percentage of California's existing capacity should be renewables based. Therefore, existing renewable energy capacity could decline 
precipitously, especially because California is not in great need of new generating capacity (CEC 1995). ${ }^{3}$ However, the statute contains enough language on encouraging and promoting renewables that some argue it could be interpreted as a minimal percentage level for renewables capacity. These issues bring up the question of how a policy promoting renewables would be enforced if renewable capacity or generation falls below a certain level. ${ }^{4}$

\section{Market Power}

The Knight proposal concludes that requiring investor-owned utilities to divest or spin-off their generating assets would mitigate concerns about potential market power. It also would provide an estimate of the market value of utility generating assets that could be used in determining stranded cost recovery for utility assets with book value in excess of market value.

The majority proposal notes the provision in FERC's open-access Notice of Proposed Rulemaking that calls for utilities to functionally unbundle by separately stating rates for transmission and ancillary services and taking these services for itself under the same open-access tariff that is available to others (FERC 1995). The majority calls for utilities to functionally unbundle the distribution, transmission, and generation elements of their system. Their proposal notes the potential for market power in generation, especially with Pacific Gas \& Electric and Southern California Edison, but simply requests comments on the issue.

The majority proposal would require FERC's approval and oversight because it orders utilities to interconnect in a type of power pool, essentially creating a wholesale power pool. A critical FERC decision will be whether to allow power sold into the pool to be sold at market-based rates. The Federal Power Act requires wholesale power to be sold at "just and reasonable" rates; various courts have interpreted this to mean cost-based rates with a rate of return. In recent years, FERC has allowed market-based rates if competitive forces exist to drive rates to a "just and reasonable" level, and the seller does not possess market power or control market entry or exit (Tenebaum and Henderson 1991). The pool does not cap power sales into the pool at cost-based rates but sets a market clearing price; an important question is whether investor-owned utilities in California possess too much market power to allow market-based rates. FERC Commissioner William Massey discussed this in a recent address delivered in England:

... if FERC were to find that California utilities have market power and thus are not eligible for selling power to poolco at rates exceeding their costs, the key philosophical underpinning of the pool would be eroded. . . . One possible remedy mentioned in [the majority proposal] is the divestiture of generating facilities. In fact, that is a key component of Commissioner Knight's dissenting proposal. . . . [This] may be the most important issue in FERC's review of any poolco proposal. From what I've read and heard, market power may be causing significant pricing distortions here in the United

\footnotetext{
${ }^{3}$ The CEC said San Diego Gas \& Electric, Sacramento Municipal Utility District, and Imperial Irigation District need capacity through its 12-year forecast. Pacific Gas \& Electric and Southern California Edison do not need capacity until at least 2003, assuming the winning bids from the BRPU are included; FERC determined these bids do not meet PURPA's requirements.

${ }^{4}$ For a description of how the portfolio standard could be implemented under a central pool, see Rader, Nancy. Comments of the American Wind Energy Association and the Union of Concerned Scientists on the Alternative Proposals Issued May 24, 1995, to Restructure California's Electric Services Industry and Reform Regulation, July 24, 1995, Docket No. 4. 94-04-031/. 94-04-032.
} 
Kingdom. If the same potential arises in California, I believe regulators, at both the state and federal levels, will need to take a serious look at possible remedies (Massey 1995).

Neither proposal addresses the potential for market power associated with ownership of transmission and distribution facilities. Each seems satisfied that simply transferring the dispatch and control functions to an independent system operator is sufficient. Indeed, the majority proposal recommends that transmission owners receive revenues or royalties from the pool. Transmission is the means by which competing sellers can deliver their services to buyers; therefore, transmission plays a central role if greater competition is going to occur. The owners of transmission assets are often investor-owned utilities whose ownership of a majority of generation assets is drawing attention; market power concerns are not just limited to generation. However, California has limited jurisdiction in this area. Any sale, disposition, or transfer of transmission would require FERC approval under the Federal Power Act.

\section{Qualifying Facilities}

Both proposals would honor existing QF contracts and include QFs as part of a stranded cost recovery mechanism should QF contract rates exceed market rates. All QF power purchase costs above the market-driven rate would be part of a transition cost line item on a customer's bill instead of being rolled into a customer's electric rates. The majority proposal substitutes the pool price for the market price and determines stranded cost recovery by comparing total contract costs with the product of the pool price and energy purchases. The Knight proposal creates an annual balancing account and defines a "proxy market price" as either the distribution utility's average annual procurement cost less QF contracts or an annual power price index. The amount in the balancing account would be determined by subtracting the proxy market price from total QF contract costs.

QF contract renegotiation is part of both proposals, although each would distribute the gains differently. The Knight proposal would allow utility shareholders to retain 50\% of any "demonstrable net savings" if the renegotiated contracts could be shown to reduce overall consumer costs. It specifically calls for any rate reductions from year-11 QF contracts to be passed on to ratepayers and not kept to finance the acceleration of any stranded cost recovery mechanisms, stating that "consumers have expected and ought to receive the benefits of those reductions." In contrast, the majority proposal would allocate $50 \%$ of any declining expenses from year-11 QF contracts to accelerate the stranded cost recovery of QF contracts. The majority proposal also would allow utility shareholders to retain $20 \%$ of the savings of renegotiated QF contracts. It calls for revising the short-run avoided cost methodology so that it is based on the pool's price rather than short-term fuel prices.

Both proposals suggest that a tradeable renewable energy obligation, as proposed by the portfolio standard, would encourage renewable energy QFs and utilities to restructure existing contracts. It is not clear how this would happen, unless a $\mathrm{QF}$ believes such as program would make its project more attractive to a central pool or a direct access participant.

\section{Performance-Based Ratemaking and Incentives}

Both proposals endorse PBR for utility customers; the majority goes even further by suggesting it be applied to transmission pricing and adding additional transmission capacity. The majority proposal notes that PBR will be individually tailored for each utility, although there are likely to be common features with each PBR.

The potential impact of PBR on renewables, or resource acquisition in general, has not been widely deliberated in the renewables community. Nevertheless, the PBR structure could be critical in determining whether or not a distribution-type utility pursues renewables. These utilities retain 
considerable market power in both proposals-they serve all retail in the majority proposal, while a distribution utility in the Knight proposal could retain many existing utility customers. One concern is that a PBR may be designed to simply allow utilities to recover fuel costs without exposing utilities to the possible risk of increasing fuel costs. This would remove a primary advantage of renewable energy technologies because the cost of renewable is not affected if the price of fossil fuels increases (Hamrin et al. 1994). PBR also is somewhat like a near-term discount plan; it remains to be seen whether it can be adapted as a long-term resource acquisition mechanism as well..$^{5}$ For this reason, a well-designed PBR that is at least not adverse to renewables may be important for the renewable energy community.

Both proposals recommend incentives for utilities to pursue competitive generation supplies. The Knight proposal calls for an incentive to distribution utilities to ensure that the utility aggressively exploits the competitive market for generation services on behalf of consumers who choose to remain as utility customers. The majority proposal also supports such an incentive, suggesting that "an appropriate incentive mechanism will encourage generators to bid properly and competitively into the pool. It will also prevent gaming of bids and market power problems and at the same time minimizes reliance. on transition charges by separating operation from capital cost."

A feature of PBR is rewarding utility shareholders if a utility performs well above forecasts or expectations. Indeed, a critical component of PBR is designing the targets such that a utility is significantly but not impossibly challenged to achieve them. If direct incentive payments are called for to exploit competitive opportunities, then that seems almost at odds with the impetus behind both proposals to exploit competitive generation opportunities that are already present.

\section{Transmission Expansion and Pricing}

The Knight proposal is largely silent on transmission siting and pricing. In contrast, the majority proposal covers these issues in some detail. It suggests that "congestion experienced by the pool" will indicate the need for new transmission facilities, and the pool can build the facilities and be compensated by transmission revenues received by the pool. The majority proposal wants the pool to submit to FERC a transmission pricing methodology that includes a factor for congestion "to encourage efficient transmission investment." The majority also plans to recommend that FERC adopt PBR as a means of encouraging investment in new transmission facilities.

Congestion pricing may not encourage transmission owners to build new capacity but to collect monopoly rents. If not carefully designed, FERC could also view congestion pricing as a form of "and" pricing (rolled-in, system-wide costs or "embedded costs" plus the congestion cost), which FERC considers double-counting and not meeting the "just and reasonable" standard under the Federal Power Act.

The two proposals mirror a national industry debate on transmission pricing. A central component is a trade-off between traditional pricing based on rolling in and averaging the costs of the entire transmission system ("embedded cost") and new transmission pricing methodologies that are more precise and track power flows but are more complex and perhaps difficult to administer. Embedded cost pricing, while simple to administer, may not properly compensate transmission owners for each transaction (FERC 1993). The two proposals also differ in their approach toward transmission transactions. Although not explicitly, the Knight proposal appears to rely on "contract-based" transmission where a contract specifies

\footnotetext{
${ }^{5}$ Some discussion in California is also being devoted to including the fixed costs of utility generation assets of PBR. Utilities would be at risk for recovering the variable costs of thermal units based on the pool price. This would be restricted to utility fossil plants because the majority proposal automatically dispatches QF, nuclear, and hydro plants. Personal Communication, David Morse, California Division of Ratepayer Advocates, August 23, 1995.
} 
a particular transaction, even though the electrons may not actually flow that particular way. In contrast, the majority proposal, with its congestion pricing, seems more concerned with the flow of electrons.

It is also unclear who is responsible for building new transmission and how the pool interacts with the Western Regional Transmission Association (WRTA). Presumably, planning and transmission capacity expansion issues are being left to the WRTA, although that is not explicit in the majority proposal. If planning and expansion are left to the poolco, then decisions and cost allocation may be left to a small group made up largely of transmission owners, further heightening concerns about market power. ${ }^{6}$

Finally, the majority proposal does not seem to allow competition for ancillary services, although this is not clear. Presumably, the pool would provide ancillary services. The Knight proposal assigns load following, reactive power support, and system protection to OPCO, but suggests that other services like loss compensation and spinning reserves could be purchased competitively.

\section{Stranded Investment}

Both proposals would recover stranded costs through a separate charge on all customer bills, but the proposals use different methods for determining stranded investment. The Knight proposal recommends divestment or spin-off of existing investor-owned utility plants to determine the market value of the plants. Should the proceeds not be enough to meet the book value of the plants, the shortfall would be part of stranded cost recovery, which the Knight proposal would recover through local distribution rates. Utilities would recover $90 \%$ of the stranded generation costs; $10 \%$ would flow back to ratepayers (utilities would recover $100 \%$ of QF payments that exceed market rates). The Knight proposal calls for a formal proceeding to determine which is distribution and which is transmission, and would submit the results to FERC for approval. The Knight proposal believes that meter and billing services are local distribution services supplied to every retail customer, no matter what the voltage level.

The majority proposal defines the market value of utility generation assets as the net present value of the revenues from electricity sales from utility generation facilities. The majority proposal would hold annual proceedings to compare actual pool prices with the market value of utility generation assets. Nuclear and hydro assets would be combined to minimize stranded cost. A different procedure would be used for fossil and geothermal units. The majority proposal suggests a floor and ceiling on rate of return for these assets. The floor would be 150 basis points below a utility's authorized rate of return; the cap would be 150 basis points above. In other words, if a utility's rate of return is $10 \%$, it would receive stranded investment compensation if the rate of return from its power plants was under $8.5 \%$. If a utility sells or spins off its units, then the majority would use the sale or stock price as the market mechanism.

The majority proposal will be controversial because it guarantees $100 \%$ cost recovery and raises the prospect of utilities gaming the pool by bidding to keep the pool price low, shutting out new entrants who cannot compete at that low price, and then recovering the difference through a stranded cost recovery mechanism. The two proposals also illustrate the trade-offs in considering recovery of stranded costs. While the Knight proposal of divesting or spinning off generating assets may result in a more accurate market value, California investor-owned utilities are not likely to embrace a forced divestiture or spin off. The majority proposal avoids the controversy over divestiture but embraces a complicated and possibly cumbersome annual administrative procedure. The majority proposal also assumes that the lower-cost

\footnotetext{
${ }^{6} \mathrm{An}$ interesting wild card is Pacificorp's proposal to form a west-wide transmission company that would own, operate, and coordinate all the high-voltage electric transmission facilities in the western United States. In a hybrid case, a single transmission operator would own some facilities but lease and contract transmission from other owners. See "Pacificorp Leading Talks on Creating Transmission Company for Entire West," Electric Utility Week, August 7, 1995, pp. 1, 10-11.
} 
hydro plants can more or less offset the higher-cost nuclear plants enough to lower, if not avoid, stranded investment recovery. This may be true for Pacific Gas \& Electric, which has significant hydro resources, but the majority proposal notes that San Diego Gas \& Electric and Southern California Edison have little or no hydro resources and will likely need stranded cost recovery to offset their nuclear plant investments. 


\section{Jurisdictional Issues}

As might be expected, federal and state jurisdictional issues surround both proposals.

The majority cites one advantage of its proposal as retaining the present federal-state jurisdictional boundaries that govern today's electricity industry. It notes that utilities will still make retail sales, which will be subject to CPUC jurisdiction. The majority also notes that the establishment of a wholesale pool will require FERC's approval. Therefore, the wholesale-retail distinction will be retained. The majority is concerned about implementing direct access until FERC more clearly defines the jurisdictional boundary between transmission-traditionally wholesale and FERC regulated-and distribution, which is state regulated. The majority believes recovery of retail stranded costs will be tied to some sort of nonbypassable fee on distribution. Until the boundary between transmission and distribution is clear, the majority believes direct access could involve some customer classes bearing greater costs and risks than other customer classes, which the majority opposes.

The majority invited comment on whether the CPUC has the authority to compel utilities under its jurisdiction to form and participate in a poolco. Pacific Gas \& Electric's comments to FERC in the Notice of Intent (NOI) on Alternative Power Pooling Institutions suggest that Section 202(b) of the Federal Power Act prohibits states from ordering the establishment of a wholesale power pool. As drawn from the majority proposal, Section 202 essentially allows FERC to order sales and exchanges over existing interconnections and to order new interconnections, sales, and exchanges. Section 202(b) specifically states that

Whenever the Commission, upon application of any State commission . . . finds such action necessary or appropriate in the public interest it may by order direct a public utility (if the Commission finds that no undue burden will be placed upon such public utility thereby) to establish physical connection of its transmission facilities with the facilities of one or more other persons engaged in the transmission or sale of electric energy, to sell energy to or exchange energy with such persons. ${ }^{?}$

Pacific Gas \& Electric apparently believes that "upon application of any state commission" precludes the CPUC from directly ordering utilities to participate in a pool. Pacific Gas \& Electric may be softening its position, however. The company said it would participate in a pool if the CPUC ordered it to do so (Electric Utility Week 1995b). In addition, PG\&E said it was encouraged by the principles agreed upon by Southern California Edison and other parties mentioned earlier in this paper (Electric Utility Week 1995c).

Others contend that the exclusive federal jurisdiction over transmission and wholesale sales aside from Pacific Gas \& Electric's concern precludes the CPUC from ordering utilities to participate in a pool. The majority believes the Congress did not intend to discourage states from pursuing innovative mechanisms, even if federal approval is required. The majority proposal recognizes FERC's jurisdiction over the pool but believes the CPUC can order investor-owned utilities to use the pool to dispatch power that serves retail ratepayers.

An interesting question is how loosely or rigorously FERC would administer a poolco. It is possible that after a fairly rigorous review FERC would essentially let the pool run itself and only act upon complaints by other parties. FERC likely would ensure that the poolco offers comparable service to all wholesale parties on a nondiscriminatory basis; this requirement is built into the majority proposal. On the other

\footnotetext{
${ }^{7}$ The Federal Power Act, 16 U.S.C. § 824a(b).
} 
hand, FERC has expressed increasing skepticism that a traditionally constructed pool can operate in a competitive industry without violating the "undue discrimination" provisions of the Federal Power Act. It has challenged power pools to demonstrate otherwise. Traditionally, power pools have been a closed society orchestrated by the transmission-owning "haves," often to the detriment of those who do not own transmission, or the "have-nots."

The Knight proposal presumes the state can order retail wheeling, but that is very much in dispute. The Energy Policy Act of 1992 (EPAct) stipulated that nothing affects the authority of state or local governments under state law "concerning the transmission of electric energy directly to an ultimate consumer." Depending on how it is interpreted, the "savings clause" in EPAct allows states to order retail wheeling; preserves existing state law governing retail wheeling but does not allow other states to order retail wheeling; or does not allow states to order retail wheeling at all (Edelston 1994). Should California adopt anything like the Knight proposal, it likely will be legally challenged.

The Knight proposal predicts an explosion of participants offering various services should a retail wheeling regime be adopted. Yet a combination of existing state and federal laws may prevent many nonutility companies from making retail sales. EPAct flatly prohibits exempt wholesale generators (EWGs) from making retail sales, while QFs could make retail sales but could not mandate a utility power purchase or sell at avoided cost, as specified by PURPA. A QF selling at retail would still be exempt from the Public Utility Holding Company Act (PUHCA).

Nothing in federal law prevents a company from creating a corporation that resembles a QF or EWG (but does not apply for formal certification as a QF or EWG) and develops and/or owns generators that sell power at retail. However, PUHCA prevents the creation or operation of power companies that are not integrated with each other. In other words, a company could not own generating companies that are located on either coast because they are not integrated with each other. Because of this PUHCA requirement, the only companies that can legally sell at retail would be the following:

- Existing retail utilities located nearby a California utility

- A new, non-EWG retail generating company whose only business is selling power at retail in a California utility's service territory

- A corporation with separate, non-integrated utility or generating divisions, rather than separate corporations.

Recently, Congressman Dan Schaefer (R-CO), the chair of the House Energy and Power Subcommittee, expressed his support for a comprehensive overhaul of the federal statutes related to electric power, including PUHCA. Rep. Schaefer called for deregulating the electric power industry and allowing for full competition (Schaefer 1995).

Other elements of both proposals are probably a test of CPUC's existing authority and may require new legislation. The Knight proposal calls for divestiture or spin-off of a utility's generating assets; the majority proposal asks for comment on this approach. Some have expressed doubt that any state has the authority to order divestiture. FERC approval may be required if utility generating facilities used in wholesale transactions are to be sold or spun-off to shareholders. Additional approvals by FERC and the Nuclear Regulatory Commission may be necessary to transfer the ownership of hydro and nuclear licenses. Stranded cost recovery also could require state legislation. An interesting question is whether Knight's proposal of flowing $10 \%$ of retail stranded cost recovery to ratepayers may be challenged at FERC as not allowing full recovery of "legitimate and verifiable costs." 


\section{New Initiatives}

\section{The Memorandum of Understanding}

In September 1995, Southern California Edison (SCE), the California Manufacturers Association, the California Large Energy Consumers Association, and the Independent Energy Producers submitted a memorandum of understanding (MOU 1995) to the CPUC. The MOU combines elements of both of the CPUC proposals, and the parties involved call it a compromise to move the restructuring process forward (Electric Utility Week 1995a). Certain provisions in the MOU apply to the three major California investor-owned utilities, but some of the provisions are specific to SCE. The MOU calls for the following:

- A voluntary wholesale power pool, known as the power exchange, will be created by January 1 , 1998.

- Direct access will be phased in over 5 years. Bilateral contracts between customers will be limited to 125 participants at a maximum of $8 \mathrm{MW}$ for each customer, with a total cap of $800 \mathrm{MW}$ in the first year. This will gradually increase to allowing direct access for all customers by 2002 . All customer classes, such as agricultural, educational, small commercial, and residential, will have the chance to participate in each phase-in schedule. Customers can also join together and aggregate their loads. Customers will be allowed to aggregate electric power loads from a single site or from several sites.

- An independent system operator (ISO) will oversee the scheduling and dispatch of all electricity on the state's power grid. The ISO also will be responsible for maintaining transmission system reliability and safety; providing nondiscriminatory and comparable access to all participants; and providing information on the system status, constraints, and load distribution on a nondiscriminatory basis to all market participants. The ISO will not be owned or controlled by any utility that owns generation, transmission, or distribution facilities, nor will the ISO have any financial interest in any generation facilities.

- All California utilities-including municipal utilities and public power authorities or their affiliates-that use the ISO to schedule direct access sales to the retail customers of other California utilities must offer reciprocal opportunities for direct access sales to their retail customers. (The parties that signed the MOU also promised to support the California utilities' efforts to promote direct access to retail customers in other western states.)

- Except for ancillary services, any available generation not committed through bilateral contracts between sellers and customers must bid in the power exchange. The power exchange will create a short-term pool for buyers and sellers. The ISO will share load data with the power exchange so it can secure resources needed to meet the loads not served by bilateral contracts. For a transition period of 5 years, investor-owned utilities in California will bid all of their generation, QF (qualifying facility) contracts, and other contracts into the power exchange, but utilities will not have to purchase all of their energy requirements from the power exchange.

- A nonbypassable, "competitive transition charge" (CTC) will be developed to cover the above-market costs of SCE's generation assets, QF contracts, and regulatory assets that may not be recoverable in a more market-oriented electric power industry. During a transition period, CTC determinations will be made annually by comparing the authorized revenues for each generating asset with the revenues received by sales into the power exchange. SCE will minimize the CTC through contract 
renegotiations with QFs and performance-based incentive mechanisms for its generating plants. The CTC should fully recover SCE's stranded asset costs by 2004, except for QF contracts and regulatory assets, which will be recovered over the life of those obligations.

- After the transition period, defined as 5 years, a market valuation will occur for SCE's hydro and fossil plants, as well as SCE's $14 \%$ share in its Palo Verde nuclear plant. The market value of the fossil and hydro plants will be based on appraisal, spin-off, or sale, and the plants will compete in the market based on the fixed costs of each plant. SCE will accelerate recovery of its investment in Palo Verde at a reduced rate of return over 7 years beginning in 1997, and SCE will have to sell its interest in Palo Verde within 5 years. Similarly, SCE will also accelerate recovery of its investment in the San Onofre nuclear plants, and those plants will be market-valued in 2004.

- Costs for existing QF contracts will be fully recovered. Above-market cost payments to QFs, defined as the revenues SCE will receive from selling the QF power to the power exchange, will be separated out from contract payments to QFs to determine the CTC that SCE can recover. The parties of the MOU expect to propose guidelines to the CPUC for voluntary renegotiation of QF contracts. The guidelines include accelerating the recovery of contract capacity payments over a shortened period of time, conditioned on plant performance; an energy price schedule alternative to short-run avoided costs that is now based on current fossil fuel prices; and voluntary early contract termination.

- Existing environmental, social, demand side management, and renewable energy programs will be funded by a nonbypassable customer charge. Expenditures cannot exceed $3.3 \%$ of utility total revenue requirements as of the beginning of 1995.

- A plan and schedule will be prepared to address market power concerns. The plan and schedule will be presented to the Federal Energy Regulatory Commission (FERC) in early 1996, and a specific proposal will be presented to FERC 18 months after the power exchange is established. SCE will propose performance-based ratemaking for its generation plants to cap revenues from these plants as a curb on SCE's market power. All market power issues for all three California investor-owned utilities would be resolved 5 years after the pool begins operating.

Several industry organizations are pushing the CPUC to consider the MOU as the leading electric utility restructuring proposal in California, rather than the majority proposal. Comments filed at the CPUC mostly supported the MOU over the majority proposal. However, two broad-based coalitions submitted statement of principles expressing their differences with the MOU over market power, stranded cost recovery, public policy programs and the timetable for implementing direct access. The two statement of principles are summarized below (Electric Utility Week 1995d).

\section{Customer Groups}

The CPUC's Division of Ratepayer Advocates (DRA) sponsored these principles with 11 large industrial and agricultural consumer groups and public agencies. The 11 groups are the following: Association of California Water Agencies, Agricultural Energy Consumers Association, California City-County Street Light Association, California Department of General Services, California Farm Bureau Federation, California Hotel and Motel Association, California Industrial Users, California League of Food Processors, California Restaurant Association, California Retailers Association, and School Project for Utility Rate Reduction.

The customer groups hail the MOU as a better starting point for electric utility restructuring than the CPUC's majority proposal. They also call on the CPUC to find that any restructuring policy or strategy 
will lead to short- and long-term bill and rate reductions for all utility customers. These groups assert that "arbitrary caps, meter requirements or other barriers" should not be used to prevent all customers from taking advantage of direct access. Finally, the customer groups recommended that local governments be allowed to aggregate small commercial and residential electric demand loads.

On stranded costs, the customer groups state that the problems that confront utilities "are neither . . . of their own making nor entirely beyond their control and responsibility," but the customer groups believe that utility shareholders have been compensated for business and competitive risks for many years. They believe stranded costs should be strictly and narrowly defined to include sunk costs and costs from existing contractual obligations, not future costs associated with currently operating utility assets. Stranded costs from QF contracts and other power purchase contracts should be mitigated as much as possible, including but not limited to contract renegotiation.

The customer groups recommend that market power issues must be addressed and resolved as early as possible, rather than studied and presented as a plan to FERC after the power exchange is operating, as proposed in the MOU. These groups believe that utilities should develop plans that promise a "rapid transition" that separate the competitive and monopoly functions of today's vertically integrated utilities.

The customer groups endorse the continuation of public policy programs (energy efficiency, renewable energy, research and development, and low income assistance) financed by a nonbypassable charge. Except for low-income programs, the customer groups advocate capping the funding "that would allow their cost-effective continuation," with a review after 5 years to assess the programs' effectiveness and value. Low-income programs would be funded based on need, and the customer groups believe that lowincome programs will need to be funded even after the electric power industry shifts to competition. These groups do not support the continued administration of these programs by utilities, or for utilities to receive the program funding. The customer groups realize that utilities may need to administer the programs during a transition period but recommend the termination of any utility involvement after the end of 1997 (DRA 1995).

\section{Environmental, Public Interest, and Renewable Energy Groups}

A coalition of 11 environmental, public interest, and renewable energy groups (hereafter the environmental and public interest groups) drafted the Framework for Restructuring in the Public Interest. The 11 groups include the Utility Consumers Action Network, Union of Concerned Scientists, Toward Utility Ratepayer Normalization, Sierra Club of California, Public Citizen, Natural Resources Defense Council, Environmental Defense Fund, Center for Energy Efficiency and Renewable Technologies, California Public Interest Group, California Nevada Community Association, and the American Wind Energy Association.

The environmental and public interest groups shared many of the customer groups' goals and principles. Three key differences separate the two groups. The customer groups call for the termination of utility involvement in public policy programs. The environmental and public interest groups agree to work in good faith to find new institution or structure for implementing and delivering energy efficiency programs, but they do not call for the end of utility involvement in other public policy programs. The environmental and public interest groups recommend the portfolio standard or a renewables development fund, whereby renewable energy companies would competitively bid for those funds, to meet the state's renewable energy statutory requirements. The customer groups do not recommend any specific strategy. They also believe public policy funding should be capped and reviewed after 5 years; the environmental and public interest groups do not recommend a cap or a review. 
The environmental and public interest groups believe a primary goal of restructuring is to lower electric rates for all customers, and they suggest several ways of achieving lower rates. They include reducing "substantially below $100 \%$ " allowable costs for stranded cost recovery for utilities; improving operational efficiencies besides layoffs that "imperil customer service and system reliability"; and replacing less efficient generation plants with energy efficiency improvements and nonpolluting generating plants. They also recommend that consumer protection and state licensing standards be applied to all retail power suppliers, including the use of CPUC-sanctioned dispute resolution procedures and customer recourse options if a power supplier defaults on its contract.

For stranded costs, the environmental and public interest groups join the consumer groups in contending that a utility's authorized rate of return included a risk premium for business and competitive risks, so utilities have already been at least partly compensated for the risk that some of their assets would be rendered uneconomic by market forces. The environmental and public interest groups believe any utility stranded cost recovery should be adjusted downward to recognize the past recovery of this risk premium. The groups also believe that utilities should not be guaranteed $100 \%$ stranded cost recovery in order to provide utilities with "clear and strong incentives" to mitigate the costs that could be considered stranded.

The environmental and public interest groups continue by defining stranded costs as the difference between the "sunk, unavoidable, undepreciated capital costs" for existing utility generating plants and the market value of those assets. They point out that this definition excludes the capital and operating costs for operating the plants in the future, and they indeed recommend that stranded cost recovery should not be linked to continued operation of the utility generating plants. The groups pointedly exclude a utility's past or pending cost recovery arrangements with its nuclear plants, such as SCE's SONGS and Palo Verde nuclear plants, stating that stranded cost recovery should be consistent and comprehensive and not done on a piecemeal basis.

The environmental and public interest groups recommend that the CPUC address market power issues as part of the restructuring process, not after restructuring has been implemented. The groups believe all generation plants must meet the same environmental standards and that local distribution utilities must divest of their generation assets. The groups also support the creation of an independent system operator (ISO) and a voluntary flexibility power pool but believe utilities or other bulk power suppliers should be free to supply or purchase only a part of their generation to the pool, or not participate at all. The groups also recommend that the ISO and the pool accommodate as-available and intermittent renewable resources. The environmental and public interest groups also call for direct access to be available to all customer classes simultaneously, with no artificial limits or restrictions placed on the ability of small customers to participate. They also call for facilitating the aggregation of the electric demand loads of small commercial and residential customers.

The environmental and public interest groups believe that restructuring could have an adverse impact on low-income customers and call for the creation of a lifeline-like rate, similar to the Universal Lifeline Telephone Service fund in the telephone industry, to assist low-income customers. These groups also call for the restoration of funding to 1993 levels for research and development (R\&D) in energy efficiency and renewable energy and energy efficiency and energy conservation programs. The environmental and public interest groups note that 1993 was when the CPUC began its restructuring proceedings and also before utilities began reducing their R\&D funding and their contributions to organizations such as the Electric Power Research Institute and the California Institute for Energy Efficiency (Framework 1995). 


\section{Conclusion}

With their two restructuring proposals, the CPUC continues on its long road toward restructuring the electric power industry in California. It appears, however, that industry stakeholders are driving the restructuring process forward. Several stakeholders harshly criticized the central pool concept advocated by the majority of the CPUC, and there is increasing pressure to replace the majority proposal with the MOU, which replaces the mandatory pool with a voluntary pool and phases in direct access.

Regardless of what policy the CPUC ultimately adopts, a number of governmental bodies will play a role in the restructuring process. The California state legislature will likely have to overhaul state statutes related to electricity. State legislators also may be under some public pressure to protect public policy goals such as energy efficiency or renewables.

At the federal level, the creation of a voluntary or central pool and an independent system operator effectively produces a wholesale power institution and requires FERC's approval. Because the pool's transactions will be priced on a market basis, FERC will pay close attention to whether utilities in California have market power in generation or transmission. All of the various proposals in California contemplate or recommend open access in transmission to all parties, and FERC will likely codify this requirement in any order they issue. However, various parties may ask FERC to force utilities to divest or spin off their generation assets as a means of mitigating the utilities' market power in generation. Beyond that, congressional changes to federal statutes, such as the Public Utilities Holding Company Act, also will be necessary to fully allow market participants to sell power at retail in California.

Stranded cost recovery remains a divisive issue that continues to separate the stakeholders in California. In the MOU, SCE appears to have made some key concessions, such as eventually allowing other competitors to compete directly with SCE for SCE's retail customers, in order to fully recover the abovemarket costs of its nuclear plants. Several industrial, consumer, and environmental groups have criticized the MOU for promising SCE full stranded cost recovery. These groups believe that SCE's rate of return has partly compensated SCE for any market risk it faces for assets rendered uneconomic, and recovery of any stranded cost should be reduced accordingly. These groups also express concern that if all of a generating plant's costs are paid for through a stranded cost recovery mechanism, a "super competitor" would be created that could lock out other competitors. For these reasons, the groups believe that a utility should not be allowed to operate a generating plant if the utility receives stranded cost payments. Or, if a utility receives these payments, it should only be compensated for the sunk costs of generating assets or from prior or existing contractual obligations but not compensated for any future costs of the generating assets.

California state law requires a certain percentage of new electric capacity to be set aside for renewables, and all of the proposals include some sort of mechanism for encouraging renewables, either through a portfolio standard or through a nonbypassable charge on consumer electric bills. Whether California, a national leader in installed renewable energy capacity, will maintain its present level of renewables is unclear. So far, the debate has focused on what mechanism to use for encouraging renewables, but not on how to implement a mechanism. Many of the renewable projects developed as QFs will be priced at short-term fuel costs once the fixed capacity payments expire, and some of these projects may not survive. Already, several biomass projects have ceased operations. A portfolio standard would guarantee some fixed level of renewable energy capacity, but the costs of this approach have not been determined. 


\section{References}

American Wind Energy Association (AWEA). n.d. A Renewables Portfolio Standard. Washington, D.C.: AWEA.

California Energy Commission (CEC). 1995. 1994 Electricity Report, Draft Final, June.

California Public Utilities Commission (CPUC). 1994a. Order Instituting Rulemaking on the Commission's Proposed Policies Governing Restructuring of California's Electric Service Industry and Reforming Regulation. California Public Utilities Commission. Docket No. R. 94-04/194-04. April 20.

California Public Utilities Commission (CPUC). 1994b. Interim Opinion: Procedural Schedule, Call for Briefs, and Applicability of CEQA. California Public Utilities Commission. Docket No. D.94-12027. December 7.

California Public Utilities Commission, Division of Ratepayer Advocates (DRA). 1995. Customer Statement of Principles on Electric Restructuring in Response to the Commission Order for Comments. California Public Utilities Commission. Docket No. R 94-04-31/1.94-04-032. October 2.

Customer-Based/Public Interest Restructuring Principles. 1995. September 13.

Edelston, B. 1994. "The Opera Ain't Over Until the Fat Lady Sings." Presented at the Power Transmission Access, Pricing \& Policy Conference, Washington, D.C., April 25-26.

Electric Utility Week. 1995a. "California PUC Expresses Guarded Interest in SoCal Ed, Groups' Restructuring Plan," September 18, pp. 9-10.

Electric Utility Week. 1995b. "Comments Pour in on California PUC's Competing Restructuring Proposals," July 31, p. 9.

Electric Utility Week. 1995c. "SoCal Ed, Big Users, NUGs Reach Plan for Retail Access Alongside Poolco," August 21, pp. 9-10.

Electric Utility Week. 1995d. "Compromise' Plan Reignites Debate Over Restructuring in California," October 9, pp. 9-10.

Fang, J. 1995. Non-PURPA Options for Renewables, Internal paper for National Renewable Energy Laboratory and Department of Energy, May. (Contact author for copy.)

Federal Energy Regulatory Commission (FERC). 1995. Promoting Wholesale Competition Through Open Access Non-Discriminatory Transmission Services by Public Utilities/Recovery of Stranded Costs by Public Utilities and Transmitting Utilities, Dockets No. RM95-8-000 and RM94-7-001, March 29.

Federal Energy Regulatory Commission (FERC). 1993. FERC Staff Discussion Paper on Transmission Pricing Issues, FERC Docket No. RM93-19000, June 30.

Framework for Restructuring in the Public Interest. 1995. October 2. 
Hamrin, J. 1994. Comments of The American Wind Energy Association, Order Instituting Rulemaking on the Commission's Proposed Policies Governing Restructuring California's Electricity Services Industry and Reforming Regulation, California Public Utilities Commission, Docket R. 94-04031/I.94-04-032, June 8.

Hamrin, J.; Marcus, W.; Morse, F.; Weinberg, C. 1994. Affected with the Public Interest: Electric Utility Restructuring in an Era of Competition. Washington, D.C.: National Association of Regulatory Utility Commissioners, September.

Independent Power Report. 1995. "BPA Wants to Drop 49-MW Project; Hints 1,145 MW of Option Plants Next." July 14, pp. 1-2.

Kito, S. 1992. Analysis of the Impact of the End of the Fixed Energy Price Period Under Interim Standard Offer 4 Contracts. Sacramento, Califomia: Califomia Public Utilities Commission, Division of Ratepayer Advocates, October.

Massey, William L., FERC Commissioner. 1995. "Federal-State Cooperation to Achieve Robust Competition," Address to International Bar Association, Hertfordshire, England. June 2.

Memorandum of Understanding. 1995. Dockets No. R94-04-031/1. 94-04-032, September 11.

Morse, D. 1995. Report on California's Biennial Resource Plan Update. Presented before the National Association of Regulatory Utility Commissioner's 1995 Summer Meetings, July 23-27, San Francisco, Calif.

Morse, D. 1994. Overview of California IRP. Presented before the National Association of Regulatory Utility Commissioners' Winter Meetings, February 27-March 2, 1994, Washington, D.C.

Savage, J.A.; O'Donnell, A. 1995. "Restructuring Horse Trading Conducted Behind the Scenes in Sacramento," California Energy Markets, August 11, pp. 10-11.

Schaefer, Dan, Congressman. 1995. "Electricity in the 21st Century: The Future Is Bright," Presented before the Republican National Policy Forum, September 26, 1995, Washington, D.C.

Tenebaum, B.W.; Henderson, J.S. 1991. "Market-Based Pricing of Wholesale Electric Services." The Electricity Journal, December, pp. 30-45.

Working Group Report: Options for Commission Consideration. 1995. Dockets No. R. 94-12-027, February 22. 


\section{Appendix}

\section{A Comparison of the Electric Utility Restructuring Proposals Before the California Public Utilities Commission}

\begin{tabular}{|c|c|c|c|c|c|}
\hline Issie & Majority & Minority & MOU & Customer & Public Interest \\
\hline Market Structure. & $\begin{array}{l}\text { Central pool. } \\
\text { Utilities would } \\
\text { transfer control } \\
\text { and dispatch of } \\
\text { transmission to } \\
\text { independent } \\
\text { system operator. } \\
\text { PG\&E, SCE, and } \\
\text { SDG\&E must } \\
\text { make all sales and } \\
\text { purchases from } \\
\text { the pool. } \\
\text { Existing QFs, } \\
\text { wholesale con- } \\
\text { tracts, utility } \\
\text { nuclear and hydro } \\
\text { plants dispatch } \\
\text { first. } \\
\text { For remaining } \\
\text { load, buyers and } \\
\text { sellers submit } \\
\text { bids; ISO posts } \\
\text { market-clearing } \\
\text { price. } \\
\text { Real time pricing. } \\
\text { Contracts for } \\
\text { differences. } \\
\text { Requires bidding } \\
24 \text { hours in } \\
\text { advance. }\end{array}$ & $\begin{array}{l}\text { Direct customer } \\
\text { access with } \\
\text { bilateral contracts } \\
\text { once certain } \\
\text { conditions met. } \\
\text { System dispatch } \\
\text { based on price } \\
\text { determined by } \\
\text { bilateral contract } \\
\text { negotiations. } \\
\text { Independent } \\
\text { system operator } \\
\text { to ensure reliabil- } \\
\text { ity and provide } \\
\text { ancillary and } \\
\text { backup services, } \\
\text { but not central- } \\
\text { ized dispatch. }\end{array}$ & $\begin{array}{l}\text { Voluntary whole- } \\
\text { sale pool. All } \\
\text { utilities must bid } \\
\text { their non-market- } \\
\text { valued generation, } \\
\text { QF, and other } \\
\text { power contracts } \\
\text { for a transition } \\
\text { period of } 5 \text { years } \\
\text { but will not have } \\
\text { to purchase their } \\
\text { energy } \\
\text { requirements. } \\
\text { All generation not } \\
\text { committed } \\
\text { through bilateral } \\
\text { contracts must bid } \\
\text { in the pool. } \\
\text { Requires bidding } \\
24 \text { hours in } \\
\text { advance. } \\
\\
\text { Direct access } \\
\text { phased in over } \\
5 \text { years. } \\
\text { Functional sepa- } \\
\text { ration of } \\
\text { independent } \\
\text { system operator } \\
\text { (ISO) and pool. } \\
\text { ISO to oversee } \\
\text { scheduling, dis- } \\
\text { patch of power on } \\
\text { grid. Provide } \\
\text { control to area } \\
\text { services, ensure } \\
\text { system reliability. }\end{array}$ & $\begin{array}{l}\text { Supports MOU } \\
\text { market structure. } \\
\text { ISO should be } \\
\text { separate from } \\
\text { voluntary pool or } \\
\text { pricing functions } \\
\text { the pool per- } \\
\text { forms. }\end{array}$ & $\begin{array}{l}\text { Supports a "truly } \\
\text { independent" ISO } \\
\text { with reliability, } \\
\text { scheduling, and } \\
\text { cransmission } \\
\text { control functions. } \\
\text { Power pooling } \\
\text { should be volun- } \\
\text { tary and flexible. } \\
\text { Market partici- } \\
\text { pants should be } \\
\text { free to provide } \\
\text { only a portion of } \\
\text { their generation } \\
\text { or to buy only a } \\
\text { part of their } \\
\text { energy needs, or } \\
\text { not to participate } \\
\text { in the pool at all. } \\
\text { All sources of } \\
\text { generation must } \\
\text { meet the same } \\
\text { environmental } \\
\text { standards, re- } \\
\text { gardless of plant } \\
\text { ownership or } \\
\text { restructuring } \\
\text { model. } \\
\text { The ISO and the } \\
\text { pool should } \\
\text { accommodate } \\
\text { intermittent } \\
\text { renewables. } \\
\text { These resources } \\
\text { should be able to } \\
\text { bid on an as- } \\
\text { available basis. }\end{array}$ \\
\hline
\end{tabular}




\begin{tabular}{|c|c|c|c|c|c|}
\hline Issue & Majority & Minority & MOU & Customer & Public Interest \\
\hline Stranded Recorety $/$ last. & $\begin{array}{l}\text { Separate, non- } \\
\text { bypassable charge } \\
\text { on customer bills. } \\
\text { Annual } \\
\text { proceedings to } \\
\text { compare market } \\
\text { value (pool price) } \\
\text { of utility assets } \\
\text { with book value. } \\
\text { Nuclear and } \\
\text { hydro units } \\
\text { combined to } \\
\text { minimize stranded } \\
\text { cost. } \\
\text { Utility sale or } \\
\text { spin-off of assets } \\
\text { would determine } \\
\text { market price, at } \\
\text { utility's option. } \\
\text { Floor and ceiling } \\
\text { on rate of return } \\
\text { for fossil and } \\
\text { geothermal } \\
\text { plants. } \\
\text { 100\% recovery of } \\
\text { QF payments that } \\
\text { exceed market } \\
\text { rate. Shareholder } \\
\text { incentives to } \\
\text { renegotiate QF } \\
\text { contracts. }\end{array}$ & $\begin{array}{l}\text { Separate, non- } \\
\text { bypassable charge } \\
\text { on customer bills. } \\
\text { Utilities must } \\
\text { divest or sell off } \\
\text { existing } \\
\text { generation assets. } \\
\text { Sale/spin-off } \\
\text { proceeds would } \\
\text { determine market } \\
\text { value. } \\
\text { Utilities recover } \\
90 \% \text { of stranded } \\
\text { costs; } 10 \% \text { flow } \\
\text { back to } \\
\text { ratepayers. } \\
\text { 100\% recovery of } \\
\text { QF payments that } \\
\text { exceed market } \\
\text { rates. } \\
\text { Shareholder } \\
\text { incentives to } \\
\text { renegotiate QF } \\
\text { contracts. }\end{array}$ & $\begin{array}{l}\text { Separate, non- } \\
\text { bypassable charge } \\
\text { on customer bills. } \\
\text { Annual } \\
\text { proceedings to } \\
\text { compare } \\
\text { authorized } \\
\text { revenues for each } \\
\text { generating plant } \\
\text { with sales into } \\
\text { pool. } \\
\text { Market valuation } \\
\text { of hydro and } \\
\text { fossil plants over } \\
5 \text { years based on } \\
\text { sale, appraisal or } \\
\text { spin-off. } \\
\text { San Onofre } \\
\text { nuclear plants } \\
\text { market-valued in } \\
2004 . \\
\text { SCE must sell its } \\
\text { interest in Palo } \\
\text { Verde nuclear } \\
\text { plant by } 2001 . \\
100 \% \text { recovery of } \\
\text { QF payments that } \\
\text { exceed market } \\
\text { rates. Calls for } \\
\text { contract } \\
\text { restructuring. }\end{array}$ & $\begin{array}{l}\text { Utilities must } \\
\text { have strong } \\
\text { incentives to } \\
\text { mitigate stranded } \\
\text { costs. } \\
\text { Shareholders must } \\
\text { bear a fair share } \\
\text { of stranded costs. } \\
\text { Stranded costs } \\
\text { should be limited } \\
\text { to sunk costs and } \\
\text { existing contracts. } \\
\text { No recovery of } \\
\text { future costs. } \\
\text { Mitigation of } Q F \\
\text { costs, including } \\
\text { but not limited to } \\
\text { renegotiation. }\end{array}$ & $\begin{array}{l}\text { Separate, non- } \\
\text { bypassable charge } \\
\text { on customer bills. } \\
\text { Recovery of } \\
\text { stranded costs } \\
\text { must be less than } \\
100 \% \text { to give } \\
\text { utilities incentives } \\
\text { to mitigate costs } \\
\text { and reduce } \\
\text { customer bills. } \\
\text { Recovery of } \\
\text { stranded costs } \\
\text { must not be tied } \\
\text { with future oper- } \\
\text { ation of the } \\
\text { generating units } \\
\text { involved. } \\
\text { Stranded cost re- } \\
\text { covery should be } \\
\text { linked to a utili- } \\
\text { ty's willingness } \\
\text { to achieve a fully } \\
\text { competitive } \\
\text { generation mar- } \\
\text { ket. } \\
\text { Stranded cost re- } \\
\text { covery should be } \\
\text { limited to sunk } \\
\text { costs, not future } \\
\text { costs. } \\
\text { Pending applica- } \\
\text { tions for cost re- } \\
\text { covery of utility } \\
\text { nuclear assets } \\
\text { cannot be basis } \\
\text { for stranded cost } \\
\text { mechanism. } \\
\text { Stranded costs } \\
\text { should be allo- } \\
\text { cated fairly } \\
\text { among all cus- } \\
\text { tomer classes. } \\
\text { 100\% recovery of } \\
\text { QF contract pay- } \\
\text { ments. }\end{array}$ \\
\hline
\end{tabular}




\begin{tabular}{|c|c|c|c|c|c|}
\hline Issue & Majority & Minority & MOU & Customer & Public Interest \\
\hline Marrset rower & $\begin{array}{l}\text { Calls on utilities } \\
\text { to functionally } \\
\text { unbundle } \\
\text { distribution, } \\
\text { generation, and } \\
\text { transmission. } \\
\text { Notes potential } \\
\text { for market power } \\
\text { in utility genera- } \\
\text { tion. Asks for } \\
\text { public comment. }\end{array}$ & $\begin{array}{l}\text { Requires utilities } \\
\text { to divest or spin } \\
\text { off generating } \\
\text { assets. }\end{array}$ & $\begin{array}{l}\text { PBR on genera- } \\
\text { tion resources to } \\
\text { act as a revenue } \\
\text { cap. } \\
\text { Agrees to resolve } \\
\text { market power } \\
\text { issues for PG\&E, } \\
\text { SDG\&E, and } \\
\text { SCE within } \\
5 \text { years. } \\
\text { Within } 18 \text { months } \\
\text { of implementation } \\
\text { of the pool, SCE } \\
\text { will file a report } \\
\text { to FERC on the } \\
\text { first year's opera- } \\
\text { tion of the volun- } \\
\text { tary wholesale } \\
\text { power pool. } \\
\text { SCE may seek } \\
\text { FERC's authority } \\
\text { for market-based } \\
\text { pricing as its } \\
\text { generation plants } \\
\text { become market- } \\
\text { valued. } \\
\text { SCE committed to } \\
\text { "certain } \\
\text { organizational } \\
\text { changes" such as } \\
\text { divestiture if } \\
\text { necessary to } \\
\text { mitigate market } \\
\text { power. }\end{array}$ & $\begin{array}{l}\text { Market power } \\
\text { issues must be } \\
\text { clearly identified } \\
\text { and resolved as } \\
\text { early as possible. } \\
\text { Must address } \\
\text { utility dominance } \\
\text { in generation } \\
\text { market in early } \\
\text { stages of restruc- } \\
\text { turing. } \\
\text { Utilities must } \\
\text { develop strategies } \\
\text { to change from } \\
\text { vertical } \\
\text { integration to } \\
\text { separate genera- } \\
\text { tion and monop- } \\
\text { oly functions. }\end{array}$ & $\begin{array}{l}\text { CPUC must } \\
\text { address and } \\
\text { resolve market } \\
\text { power issues } \\
\text { before } \\
\text { implementing } \\
\text { restructuring. } \\
\text { Suggests that } \\
\text { generation and } \\
\text { distribution assets } \\
\text { will ultimately } \\
\text { have to be } \\
\text { separated to } \\
\text { prevent conflicts } \\
\text { of interest. }\end{array}$ \\
\hline
\end{tabular}




\begin{tabular}{|c|c|c|c|c|c|}
\hline Issue & Majority & Minority & MOU & Customer & Public Interest \\
\hline PBR & $\begin{array}{l}\text { PBR for utility } \\
\text { generation and } \\
\text { distribution. } \\
\text { Propose to lobby } \\
\text { FERC to adopt } \\
\text { PBR for trans- } \\
\text { mission rates and } \\
\text { independent } \\
\text { system operator. }\end{array}$ & $\begin{array}{l}\text { PBR for all } \\
\text { monopoly func- } \\
\text { tions. }\end{array}$ & $\begin{array}{l}\text { Propose PBR for } \\
\text { fossil and hydro } \\
\text { plants by } 1997 \text {. } \\
\text { PBR also consid- } \\
\text { ered a way to } \\
\text { limit utility mar- } \\
\text { ket power. }\end{array}$ & $\begin{array}{l}\text { Want public } \\
\text { workshops to help } \\
\text { design the PBR in } \\
\text { the MOU. } \\
\text { Minimum stan- } \\
\text { dard is for con- } \\
\text { sumers to receive } \\
\text { market-priced } \\
\text { electricity, even if } \\
\text { customers of } \\
\text { monopoly utility. }\end{array}$ & $\begin{array}{l}\text { CPUC must find } \\
\text { that a PBR is } \\
\text { reasonably certain } \\
\text { to lower rates and } \\
\text { customer bills. } \\
\text { A PBR should } \\
\text { not reward a } \\
\text { utility for achie- } \\
\text { vements other- } \\
\text { wise attainable, } \\
\text { such as low } \\
\text { interest rates and } \\
\text { QF price reduc- } \\
\text { tions. } \\
\text { Fuel and pur- } \\
\text { chased power } \\
\text { adjustment ac- } \\
\text { counts should be } \\
\text { eliminated. }\end{array}$ \\
\hline Gustomer Iroad & No retail access. & $\begin{array}{l}\text { Load aggregation } \\
\text { allowed. No } \\
\text { phase-in period. }\end{array}$ & $\begin{array}{l}\text { Customer aggre- } \\
\text { gation allowed } \\
\text { but phased in } \\
\text { over } \\
5 \text { years. } \\
\text { Load can be } \\
\text { aggregated over } \\
\text { several sites, at a } \\
\text { single site, or } \\
\text { over multiple } \\
\text { customers. } \\
\text { Capacity restric- } \\
\text { tions; aggregated } \\
\text { loads initially } \\
\text { limited to } 8 \mathrm{MW} \text {. } \\
\text { Declines to } \\
50 \mathrm{~kW} \text { by } 2002 \text {. } \\
\text { Must have real- } \\
\text { time or time-of- } \\
\text { use meters. }\end{array}$ & $\begin{array}{l}\text { No unnecessary } \\
\text { caps, metering } \\
\text { requirements, or } \\
\text { other barriers. } \\
\text { Local govern- } \\
\text { ments should } \\
\text { have the right to } \\
\text { aggregate small } \\
\text { customers. } \\
\text { All customers } \\
\text { should be able to } \\
\text { opt out of the } \\
\text { program. }\end{array}$ & $\begin{array}{l}\text { Direct access } \\
\text { should be avail- } \\
\text { able to all cus- } \\
\text { tomer classes } \\
\text { simultaneously. } \\
\text { No arbitrary } \\
\text { restrictions on } \\
\text { customer aggre- } \\
\text { gation. Real-time } \\
\text { or time-of-use } \\
\text { meters for } \\
\text { aggregate small } \\
\text { customers; not } \\
\text { individually. } \\
\text { Local govern- } \\
\text { ments should } \\
\text { have the right to } \\
\text { aggregate small } \\
\text { customers. } \\
\\
\text { continued . . . }\end{array}$ \\
\hline
\end{tabular}




\begin{tabular}{|c|c|c|c|c|c|}
\hline $185 i v$ & Majority & Minority & MOU & Customer & Public Interest \\
\hline RPs & $\begin{array}{l}\text { No short-term } \\
\text { target for utilities. } \\
\text { Resource } \\
\text { diversity targets } \\
\text { could be set for } \\
\text { utility purchases } \\
\text { from the pool. } \\
\text { Portfolio stan- } \\
\text { dard. }\end{array}$ & $\begin{array}{l}\text { No short-term } \\
\text { target for utilities, } \\
\text { but "minimum } \\
\text { diversity targets" } \\
\text { could be imposed } \\
\text { if new resources } \\
\text { needed. } \\
\text { Portfolio stan- } \\
\text { dard. }\end{array}$ & $\begin{array}{l}\text { Nonbypassable } \\
\text { customer charge. } \\
\text { not to exceed } \\
3.3 \% \text { of utility } \\
\text { revenue require- } \\
\text { ments for public } \\
\text { policy programs } \\
\text { such as renew- } \\
\text { ables. }\end{array}$ & $\begin{array}{l}\text { Funding by non- } \\
\text { bypassable cus- } \\
\text { tomer charge } \\
\text { Investor-owned } \\
\text { utilities should } \\
\text { not administer } \\
\text { renewable energy } \\
\text { programs or } \\
\text { collect the funds } \\
\text { after } 1997 \text {. } \\
\text { Funding should } \\
\text { be capped. } \\
\text { Funding and } \\
\text { programs should } \\
\text { be reviewed after } \\
5 \text { years. }\end{array}$ & $\begin{array}{l}\text { CPUC should } \\
\text { ensure that } \\
\text { restructuring } \\
\text { restores and } \\
\text { improves } 1993 \\
\text { renewable energy } \\
\text { funding levels. } \\
\\
\text { Includes a } \\
\text { portfolio } \\
\text { requirement on } \\
\text { utilities to keep } \\
\text { renewables at } \\
\text { 1993 capacity } \\
\text { levels and offsets } \\
\text { above-market } \\
\text { costs of } \\
\text { renewables } \\
\text { through a system } \\
\text { benefits charge or } \\
\text { stranded } \\
\text { investment } \\
\text { recovery. }\end{array}$ \\
\hline Eor income & $\begin{array}{l}\text { Maintain present } \\
\text { programs in short } \\
\text { term. Possibly } \\
\text { transfer programs } \\
\text { to a consortium } \\
\text { or another agen- } \\
\text { cy. } \\
\text { Suggests creation } \\
\text { of universal fund } \\
\text { modeled after } \\
\text { universal charge } \\
\text { in telephones. }\end{array}$ & $\begin{array}{l}\text { Continue existing } \\
\text { programs in short } \\
\text { term. Possibly } \\
\text { transfer low- } \\
\text { income efficiency } \\
\text { programs to } \\
\text { another agency or } \\
\text { consortium. } \\
\text { Suggests creation } \\
\text { of universal fund } \\
\text { modeled after } \\
\text { universal charge } \\
\text { in telephones. }\end{array}$ & $\begin{array}{l}\text { Nonbypassable } \\
\text { charge for low- } \\
\text { income ratepayer } \\
\text { assistance. Cover } \\
\text { all eligible } \\
\text { recipients who } \\
\text { apply. } \\
\text { Nonbypassable } \\
\text { charge for low- } \\
\text { income energy } \\
\text { efficiency equiv- } \\
\text { alent to } 1995 \\
\text { levels. }\end{array}$ & $\begin{array}{l}\text { Nonbypassable } \\
\text { charge for low- } \\
\text { income ratepayer } \\
\text { assistance. } \\
\text { Funding levels } \\
\text { based on need; no } \\
\text { cap. } \\
\text { No utility } \\
\text { administration or } \\
\text { collection of } \\
\text { funds. } \\
\text { Review after } 5 \\
\text { years. }\end{array}$ & $\begin{array}{l}\text { Nonbypassable } \\
\text { charge for low- } \\
\text { income ratepayer } \\
\text { assistance } \\
\text { modeled after the } \\
\text { Universal Lifeline } \\
\text { Telephone } \\
\text { Service (ULTS) } \\
\text { charge for } \\
\text { telephones. } \\
\text { Cover all eligible } \\
\text { recipients who } \\
\text { apply. } \\
\text { Utility adminis- } \\
\text { tration until } \\
\text { ULTS charge } \\
\text { established. } \\
\text { Create a con- } \\
\text { sumer protection } \\
\text { and education } \\
\text { fund. }\end{array}$ \\
\hline
\end{tabular}




\begin{tabular}{|c|c|c|c|c|c|}
\hline Tssue & Majority & Minority & MOU & Customer & Public Interest \\
\hline DSHER\&B & $\begin{array}{l}\text { In interim, } \\
\text { continue DSM } \\
\text { programs at } \\
\text { current or } \\
\text { historical funding } \\
\text { levels. } \\
\text { For long term, } \\
\text { nonbypassable fee } \\
\text { to cover DSM } \\
\text { market } \\
\text { transformation } \\
\text { activities. } \\
\text { DSM customer } \\
\text { service-type } \\
\text { activities left to } \\
\text { competitive } \\
\text { market. } \\
\text { Ratepayer funding } \\
\text { for transmission } \\
\text { and distribution } \\
\text { R\&D only. }\end{array}$ & $\begin{array}{l}\text { In interim, } \\
\text { continue DSM } \\
\text { programs at } \\
\text { current or } \\
\text { historical funding } \\
\text { levels. } \\
\text { For long term, } \\
\text { nonbypassable fee } \\
\text { to cover DSM } \\
\text { market } \\
\text { transformation } \\
\text { activities. } \\
\text { DSM customer } \\
\text { service-type } \\
\text { activities left to } \\
\text { competitive } \\
\text { market. } \\
\text { Ratepayer funding } \\
\text { for transmission } \\
\text { and distribution. }\end{array}$ & $\begin{array}{l}\text { Funded by } \\
\text { nonbypassable } \\
\text { charge. } \\
\text { R\&D covers } \\
\text { regulated } \\
\text { transmission and } \\
\text { distribution } \\
\text { services. } \\
\text { DSM programs } \\
\text { should rely on } \\
\text { competitive } \\
\text { measures as much } \\
\text { as possible. }\end{array}$ & $\begin{array}{l}\text { Funded by non- } \\
\text { bypassable } \\
\text { charge. } \\
\text { Utilities should } \\
\text { not administer } \\
\text { programs or } \\
\text { collect funds after } \\
1997 . \\
\text { Funding should } \\
\text { be capped. } \\
\text { Review after } \\
5 \text { years. }\end{array}$ & $\begin{array}{l}\text { Funded by non- } \\
\text { bypassable } \\
\text { charge. } \\
\text { R\&D funding for } \\
\text { DSM and } \\
\text { renewables } \\
\text { should be } \\
\text { restored to } 1993 \\
\text { levels. } \\
\text { R\&D funding for } \\
\text { DSM and } \\
\text { renewables } \\
\text { should be } \\
\text { administered } \\
\text { through an } \\
\text { independent } \\
\text { institute. } \\
\text { Utility adminis- } \\
\text { tration of DSM } \\
\text { programs should } \\
\text { be continuously } \\
\text { reviewed for } \\
\text { market power } \\
\text { issues. Non- } \\
\text { utility parties } \\
\text { should be able to } \\
\text { compete with } \\
\text { utilities to } \\
\text { implement DSM } \\
\text { programs. } \\
\text { continued . . }\end{array}$ \\
\hline
\end{tabular}




\begin{tabular}{|c|c|c|c|c|c|}
\hline Issie & Majority & Minority & MOU & Customer & Public Interest \\
\hline girs & $\begin{array}{l}\text { All contracts } \\
\text { honored. Costs } \\
\text { above market } \\
\text { recovered in } \\
\text { stranded } \\
\text { investment } \\
\text { charge. } \\
\text { Utility } \\
\text { shareholders } \\
\text { retain } 20 \% \text { of the } \\
\text { savings from any } \\
\text { renegotiated QF } \\
\text { contracts. } \\
\text { Half of declining } \\
\text { expenses from } \\
\text { year-11 QF } \\
\text { contracts allocated } \\
\text { to accelerate } \\
\text { stranded cost } \\
\text { recovery of QF } \\
\text { contracts. } \\
\text { Revise short-term } \\
\text { avoided cost to be } \\
\text { based on the pool } \\
\text { price not short- } \\
\text { term fossil fuel } \\
\text { prices. }\end{array}$ & $\begin{array}{l}\text { All contracts } \\
\text { honored. Costs } \\
\text { above market } \\
\text { recovered in } \\
\text { stranded } \\
\text { investment } \\
\text { charge. } \\
\text { Utility } \\
\text { shareholders } \\
\text { retain } 50 \% \text { of the } \\
\text { savings from any } \\
\text { renegotiated QF } \\
\text { contracts. } \\
\text { Savings from } \\
\text { year-11 QF con- } \\
\text { tracts passed } \\
\text { through to } \\
\text { ratepayers. }\end{array}$ & $\begin{array}{l}\text { All contracts } \\
\text { honored. Costs } \\
\text { above market } \\
\text { recovered in } \\
\text { stranded } \\
\text { investment } \\
\text { charge. } \\
\text { Will propose } \\
\text { guidelines to } \\
\text { CPUC for QF } \\
\text { contract } \\
\text { renegotiation. } \\
\text { Options include } \\
\text { accelerating } \\
\text { recovery of } \\
\text { contract capacity } \\
\text { payments and an } \\
\text { energy price } \\
\text { alternative to } \\
\text { short-term } \\
\text { avoided costs. } \\
\\
\text { Resolve all BRPU } \\
\text { issues as soon as } \\
\text { possible. }\end{array}$ & $\begin{array}{l}\text { Supports } \\
\text { mitigation of } \\
\text { stranded costs } \\
\text { associated with } \\
\text { QF contracts, } \\
\text { including but not } \\
\text { limited to } \\
\text { renegotiation. }\end{array}$ & $\begin{array}{l}\text { All contracts } \\
\text { honored. Costs } \\
\text { above market } \\
\text { recovered in } \\
\text { stranded } \\
\text { investment } \\
\text { charge. }\end{array}$ \\
\hline
\end{tabular}

Definitions of Acronyms:

$\begin{array}{ll}\text { BRPU } & \text { Biennial Resource Plan Update } \\ \text { CPUC } & \text { Califomia Public Utilities Commission } \\ \text { DSM } & \text { Demand-side management } \\ \text { FERC } & \text { Federal Energy Regulatory Commission } \\ \text { ISO } & \text { Independent system operator } \\ \text { MOU } & \text { Memorandum of understanding } \\ \text { PBR } & \text { Performance-based regulation } \\ \text { PG\&E } & \text { Pacific Gas and Electric Company } \\ \text { QF } & \text { Qualifying facility } \\ \text { RET } & \text { Renewable energy technology } \\ \text { SCE } & \text { Southern California Edison } \\ \text { SDG\&E } & \text { San Diego Gas and Electric } \\ \text { ULTS } & \text { Universal Lifeline Telephone Service }\end{array}$




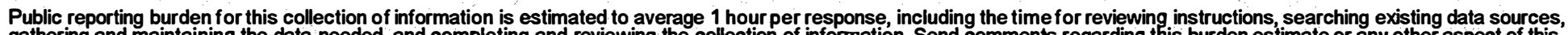

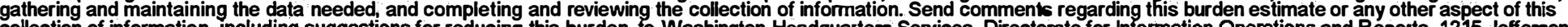

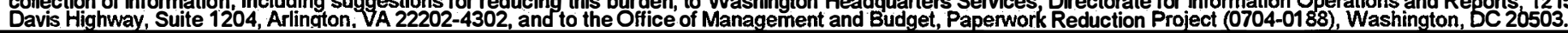
1. AGENCY USE ONLY (Leave blank)
2. REPORT DATE
November 1995
3. REPORT TYPE AND DATES COVERED
technical report

4. TITLE AND SUBTITLE

A Summary of the California Public Utilities Commission's Two Competing Electric Utility

R'estructuring Proposals

5. FUNDING NUMBERS AS115009

6. AUTHOR(S)

K. Porter

7. PERFORMING ORGANIZATION NAME(S) AND ADDRESS(ES)

National Renewable Energy Laboratory

1617 Cole Boulevard

Golden, Colorado 80401-3393

8. PERFORMING ORGANIZATION REPORT NUMBER

TP-461-8330

DE95009299

9. SPONSORING/MONITORING AGENCY NAME(S) AND ADDRESS(ES)

U.S. Department of Energy

10. SPONSORINGMMONITORING

1000 Independence Ave., SW

Washington, DC 20585

11. SUPPPLEMENTARY NOTES

12a. DISTRIBUTION/AVAILABILITY STATEMENT National Technical Information Service

12b. DISTRIBUTION CODE

U.S. Department of Commerce

5285 Port Royal Road

Springfield, VA 22161

13. ABSTRACT (Maximum 200 words)

This report summarizes the major provisions of two proposals by the California Public Utilities Commission (CPUC) for restructuring California's electric power industry and the state's regulation of it. In addition to summarizing the proposals, the report discusses the implications and issues associated with each proposal. The report also discusses how the two proposals might affect renewable energy technologies. The National Renewable Energy Laboratory prepared the report for the Office of Utility Technologies at the U. S. Department of Energy.

14. SUBJECT TERMS utility restructuring; utility regulation; electric power; renewable energy

15. NUMBER OF PAGES 30

16. PRICE CODE

SECURITY CLASSIFICATION OF REPORT

Tclassified
18. SECURITY CLASSIFICATION OF THIS PAGE unclassified
19. SECURITY CLASSIFICATION OF ABSTRACT unclassified
20. LIMITATION OF ABSTRACT UL
NSN 7540-01-280-5500

Standard Form 298 (Rev. 2-89) Prescribed by ANSI Std. Z39-1 